\title{
FAKTOR -FAKTOR YANG MEMPENGARUHI KEPATUHAN PAJAK WAJIB PAJAK ORANG PRIBADI DALAM RANGKA PENERAPAN SISTEM SELF ASESSMENT
}

\author{
Fibria Anggraini P.L \\ Fakultas Informatika Universitas Indraprasta PGRI Jakarta \\ fap102@yahoo.com
}

\begin{abstract}
ABSTRAK
Penelitian ini menganalisis faktor -faktor yang mempengaruhi kepatuhan wajib pajak orang pribadi, dengan menggunakan variabel perilaku individu,motivasi dan pengetahuan pajak sebagai variabel independen,dan kepatuhan pajak sebagai variabel dependen.Penelitian ini menggunakan analisis liniear berganda dengan software SPSS 19.0 for windows.Hasil penelitian menunjukkan bahwa perilaku individu , motivasi dan pengetahuan pajak berpengaruh terhadap kepatuhan wajib pajak orang pribadi.
\end{abstract}

Kata kunci : periilaku individu,motivasi, pengetahuan pajak dan kepatuhan wajib pajak.

\begin{abstract}
The purpose of this study was to analyze the factors that affect tax compliance (tax compliance) individual taxpayers This study uses the variable individual behavior, motivation and tax knowledge as the independent variable and tax compliance individual taxpayers as the dependent variable. Data analysis was performed using multiple linear regression analysis with SPSS for Windows Version 19.00. The results of this study indicate that individual behavior, motivation and tax knowledge have significant effect on tax compliance individual taxpayers .
\end{abstract}

Keywords: individual behavior, motivation, tax knowledge, tax compliance.

\section{PENDAHULUAN}

Sumber penerimaan negara Indonesia yang paling potensial adalah penerimaan pajak yang digunakan untuk membiayai pembangunan dan meningkatkan kesejahteraan seluruh rakyat Indonesia. Salah satu penerimaan pajak berasal dari Pajak Penghasilan (PPh). Pajak Penghasilan sendiri terbagi dua, yaitu Pajak Penghasilan yang berasal dari Badan dan Pajak Penghasilan yang berasal dari wajib pajak orang pribadi. 
Penerapan self assesment system akan efektif apabila kondisi kepatuhan sukarela (voluntary compliance) pada masyarakat telah terbentuk .Namun kenyataan yang ada di Indonesia menunjukkan tingkat kepatuhan masih rendah. Hal ini dapat dilihat dari belum optimalnya penerimaan pajak yang tercermin dari angka tax ratio (perbandingan antara jumlah penerimaan pajak dibandingkan dengan produk domestik bruto (PDB) suatu negara,Tax ratio saat ini sudah mencapai $11 \%$ namun tidak dapat tercapai karena berbagai masalah dan hanya berada pada kisaran 11\%.(Sri Mulyani, 2017). Penerimaan pajak sampai maret 2017 hanya mencapai 16,98\% dari target APBN( www.kumparan.com,2017). Hal ini disebabkan adanya tekanan perlambatan ekonomi global pada pendapatan berbasis ekspor.Mengingat kesadaran dan kepatuhan wajib pajak merupakan faktor penting bagi peningkatan penerimaan pajak, maka perlu secara intensif dikaji tentang faktor-faktor yang mempengaruhi kepatuhan wajib pajak, khususnya wajib pajak pribadi.

Berdasarkan permasalahan tersebut di atas, rumusan masalah dinyatakan apakah perilaku individu, motivasi dan pengetahuan pajak berpengaruh pada kepatuhan pajak wajib pajak orang pribadi usahawan di KPP Kebayoran Baru Tiga.Penelitian ini bertujuan untuk menganalisis apakah perilaku, motivasi dan pengetahuan pajak berpengaruh terhadap kepatuhan pajak wajib pajak orang pribadi dan bermanfaat untuk memperluas cakrawala berpikir terutama yang berhubungan dengan faktor faktor yang mempengaruhi kepatuhan pajak wajib pajak orang pribadi .

\section{LANDASAN TEORI}

\section{Teori Perilaku Terencana}

Teori Perilaku Terencana (Theory of Planned Behavior) (Ajzen, 1991 dalam Anangga 2012) digunakan untuk mengkaji perilaku individu sebagai wajib yang dipengaruhi oleh niat (intention) untuk berperilaku patuh. Penelitian mengenai perilaku ketidakpatuhan pajak yang dilakukan oleh Bobek \& Hatfield

( 2007), memodifikasi TPB dengan menambahkan tingkat kewajiban moral sebagai variabel yang turut mempengaruhi perilaku ketidakpatuhan pajak individu dan mempengaruhi ketiga variabel yang lain. Penelitian oleh Mustikasari (2007), juga memperoleh simpulan yang sama, yaitu ketiga variabel dalam TPB dan kewajiban moral berpengaruh terhadap niat dan perilaku ketidakpatuhan pajak. Blanthorne ( 2011) telah membuktikan secara empiris, bahwa kewajiban moral berpengaruh secara negatif signifikan terhadap niat ketidakpatuhan pajak.

Teori perilaku terncana dapat digambarkan sebagai berikut : 
Gambar 2.1

Teori Perilaku Terencana

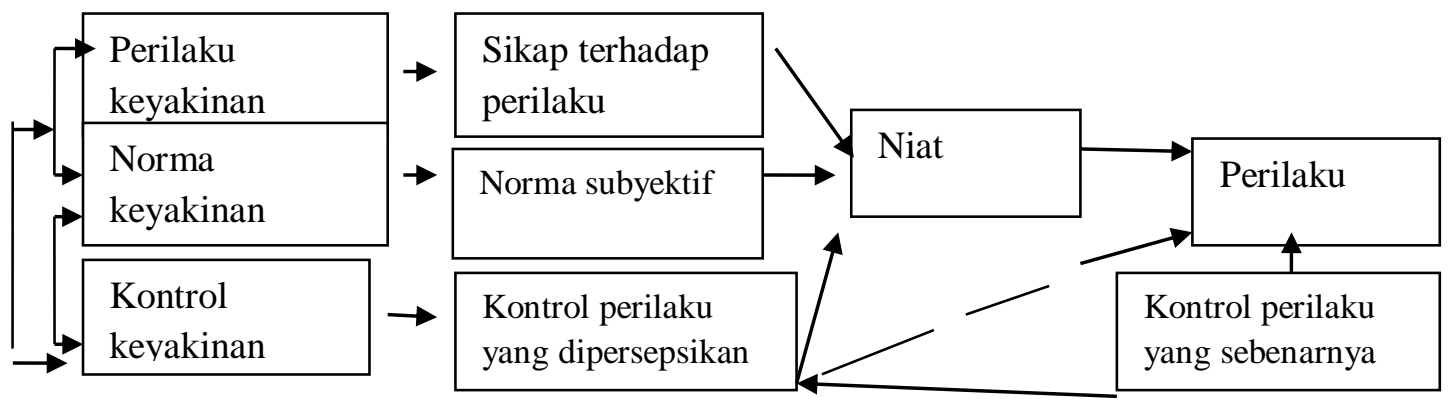

Sumber: Ajzen, I. (1991)

Pada gambar di atas secara berurutan, perilaku keyakinan menghasilkan sikap terhadap perilaku positif atau negatif, keyakinan normatif menghasilkan tekanan sosial yang dipersepsikan atau norma subjektif dan menimbulkan kontrol keperilakuan yang dipersepsikan, yang kemudian akan mempengaruhi niat dan perilaku seseorang atau individu. Perkembangan menunjukkan bahwa penelitian yang berkaitan dengan kepatuhan Wajib Pajak tidak hanya terfokus pada pembayar pajak, tetapi juga terfokus pada profesional di perusahaan yang ahli di bidang perpajakan (Pembayar pajak menggunakan tenaga ahli dibidang perpajakan untuk berbagai macam alasan, antara lain untuk mengurangi kewajiban pajaknya dan meminimumkan biaya yang berkaitan dengan perpajakan.Erwin Harinurdin ( 2009 ) memanfaatkan teori perilaku untuk menjelaskan kepatuhan pajak Wajib Pajak Badan. Semakin tinggi persepsi tax professional atas kontrol yang dimilikinya akan mendorong kepatuhan pemenuhan kewajiban perpajakan Badan.

\section{Motivasi}

Motivasi berasal dari kata Latin "movere" yang berarti dorongan atau daya penggerak. Motivasi ini hanya diberikan kepada manusia, khususnya kepada para bawahan atau pengikut .

Bentuk-bentuk motivasi, meliputi

a) motivasi instrinsik yaitu motivasi yang datangnya dari dalam diri individu itu sendiri, b) motivasi ekstrinsik yaitu motivasi yang datangnya dari luar individu, c) motivasi terdesak yaitu motivasi yang muncul dalam kondisi terjepit dan munculnya serentak serta menghentak dan cepat sekali (Widayatun, 1999). Faktor-faktor yang mempengaruhi motivasi sebagai wajib pajak antara lain a) Tingkat kematangan pribadi merupakan motivasi yang berasal dari dalam dirinya sendiri, biasanya timbul dari perilaku yang dapat memenuhi

kebutuhan sehingga puas dengan apa yang sudah dilakukan, b) Situasi dan kondisi, motivasi yang timbul berdasarkan keadaan yang terjadi sehingga mendorong 
memaksa seseorang untuk melakukan sesuatu, c) lingkungan kerja atau aktivitas merupakan motivasi yang timbul atas dorongan dalam diri seseorang atau pihak lain yang didasari dengan adanya kegiatan atau aktivitas rutin dengan tujuan tertentu, d) Tingkat pendidikan mempengaruhi engetahuan seseorang, e) Audio Visual (media) motivasi yang timbul dengan adanya informasi yang didapat dari perantara sehingga mendorong atau menggugah hati seseorang untuk melakukan sesuatu, serta sarana dan prasarana dapat mempengaruhi motivasi (Prabu,2005).

\section{Pengetahuan Perpajakan}

Pengetahuan tentang peraturan perpajakan penting untuk menumbuhkan perilaku patuh karena bagaimana mungkin wajib pajak disuruh patuh apabila mereka tidak mengetahui bagaimana peraturan perpajakan. Palil (2005) menemukan bahwa pengetahuan wajib pajak tentang pajak yang baik akan dapat memperkecil adanya tax evation. Hal senada juga dikemukakan oleh Widayati dan Nurlis (2010) bahwa wajib pajak yang mempunyai pengetahuan yang baik, akan memiliki persepsi yang positif terhadap sistem pajak yang berakibat tingkat kepatuhan pajak lebih tinggi.

\section{Kepatuhan Pajak}

Kepatuhan merupakan motivasi seseorang/ kelompok; atau organisasi untuk berbuat atau tidak berbuat sesuatu sesuai dengan aturan yang telah ditetapkan. Perilaku kepatuhan seseorang merupakan interaksi antara perilaku individu, kelompok dan organisasi. Menurut Brotodihardjo R.Soemitro (1990) bahwa secara umum teori tentang kepatuhan dapat digolongkan dalam teori paksaan dan teori konsensus. Menurut teori paksaan, orang mematuhi hukum karena adanya unsur paksaan dari kekuasaaan yang bersifat legal dari penguasa. .Teori yang disebut terakhir inilah yang sejalan dengan upaya mewujudkan kepatuhan sukarela wajib pajak. Dari definisi tersebut dapat diartikan bahwa kepatuhan memenuhi kewajiban perpajakan secara sukarela merupakan tulang punggung self assessment system, dimana Wajib Pajak bertanggung jawab menetapkan sendiri kewajiban perpajakannya, kemudian secara akurat dan tepat waktu membayar serta melaporkan pajaknya tersebut. Menurut Safri Nurmantu (2007) ada dua macam kepatuhan, yaitu kepatuhan formal dan kepatuhan material. Kepatuhan formal adalah suatu keadaan di mana wajib pajak memenuhi kewajiban secara formal sesuai dengan ketentuan dalam undang- undang perpajakan. Kepatuhan material adalah suatu keadaan di mana wajib pajak memenuhi semua ketentuan material perpajakan, yakni sesuai dengan isi dan

jiwa undang- undang perpajakan. Kepatuhan material dapat juga meliputi kepatuhan formal.

Kategori Wajib Pajak patuh sesuai dengan Peraturan Menteri Keuangan No. 192/PMK.03/2007 Jo No.74/ PMK.03/2012 adalah sebagai berikut: 
a. tepat waktu dalam menyampaikan Surat Pemberitahuan;

b. tidak mempunyai tunggakan pajak untuk semua jenis pajak, kecuali tunggakan pajak yang telah memperoleh izin mengangsur atau menunda pembayaran pajak;

c. Laporan Keuangan diaudit oleh Akuntan Publik atau lembaga pengawasan keuangan pemerintah dengan pendapat Wajar Tanpa Pengecualian selama 3 (tiga) tahun berturut-turut; dan tidak pernah dipidana karena melakukan tindak pidana di bidang perpajakan berdasarkan putusan pengadilan yang telah mempunyai kekuatan hukum tetap dalam jangka waktu 5 (lima) tahun terakhir. Berdasarkan teori diatas maka kerangka pemikiran dapat di gambarkan sebagai

berikut:

\section{Gambar 1}

Bagan Kerangka Pemikiran

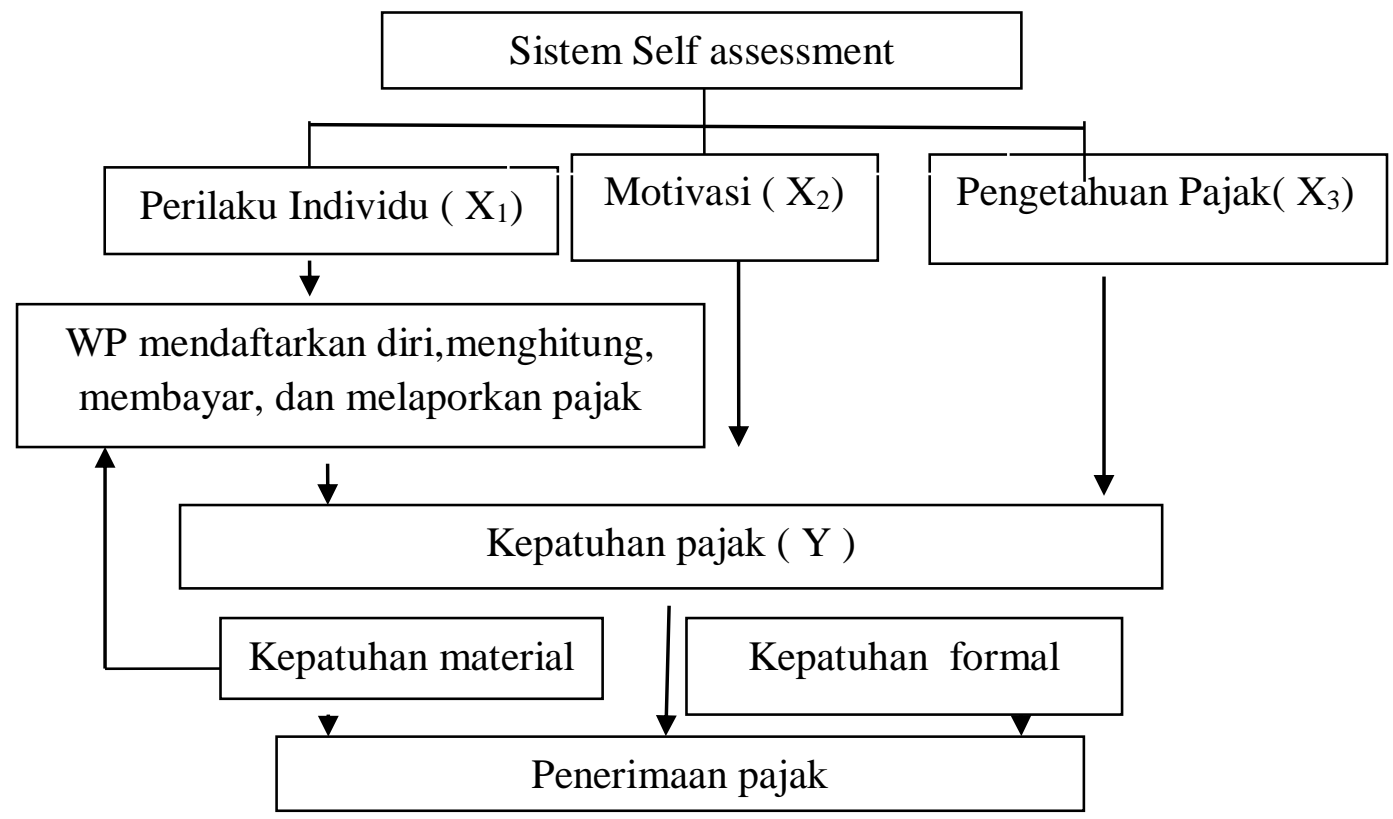

Pada sistem self assessment kepatuhan pajak sangat dipengaruhi oleh faktor perilaku individu dalam mematuhi peraturan perpajakan. Hal ini dapat dilihat dari perilaku wajib pajak dalam mendaftarkan diri, menghitung, membayar dan melaporkan pajak, baik SPT masa maupun SPT tahunan.

Selain itu motivasi dan pengetahuan pajak juga dapat mempengaruhi kepatuhan pajak ,baik kepatuhan material maupun formal. Sehingga akan mempengaruhi penerimaan 
negara dari sektor pajak. Adapun model penelitian yang ingin disampaikan peneliti dapat digambarkan sebagai berikut:

Gambar 2

Model penelitian

\begin{tabular}{|l|}
\hline Perilaku Individu $\left(\mathrm{X}_{1}\right)$ \\
\hline Motivasi $\left(\mathrm{X}_{2}\right)$ \\
\hline Pengetahuan Pajak $\left(\mathrm{X}_{3}\right)$ \\
\hline
\end{tabular}

\section{Perumusan Hipotesis}

Pengaruh Perilaku Individu terhadap Kepatuhan Pajak

Pada umumnya perilaku wajib pajak berbeda karena dipengaruhi oleh kemampuan yang tidak sama. Hal ini perlu diketahui untuk memahami mengapa wajib pajak berbuat dan berperilaku berbeda dengan yang lain dalam penghitungan, pembayaran dan pelaporan pajak terutangnya.Untuk itu hipotesis dalam penelitian ini adalah:

\section{$H_{a}$ : Perilaku individu berpengaruh positif terhadap kepatuhan pajak}

Ho : Perilaku individu berpengaruh positif terhadap kepatuhan pajak Pengaruh Motivasi Terhadap Kepatuhan Pajak

Motivasi dari wajib pajak, diantaranya adalah kesadaran pajak dari wajib pajak, tingkat kesadaran akan membayar pajak didasarkan oleh tingkat kepatuhan wajib pajak yan berpijak pada tingginya kesadaran hukum dalam membayar pajak.Dengan demikian, hipotesis dalam penelitian ini adalah:

\section{$\mathbf{H}_{\mathrm{a}}$ : Motivasi berpengaruh positif terhadap kepatuhan pajak \\ Ho : Motivasi berpengaruh negatif terhadap kepatuhan pajak}

\section{Pengaruh pengetahuan pajak Terhadap Kepatuhan Pajak}

Pengetahuan pajak merupakan seberapa besar ilmu atau wawasan tentang pajak yang dimiliki oleh wajib pajak. Pengetahuan perpajakan mengukur persepsi WP terkait dengan pengetahuan tentang tarif pajak, kewajiban dan hak, peraturan perpajakan yang berlaku, sanksi perpajakan serta perhitungan dan pelaporan pajak.

Dengan demikian, hipotesis dalam penelitian ini adalah:

$H_{a}$ : Pengetahuan pajak berpengaruh positif terhadap kepatuhan pajak Ho : pengetahuan pajak berpengaruh negatif terhadap kepatuhan pajak.

\section{METODOLOGI PENELITIAN}

\section{Populasi dan Sampel}


Populasi penelitian ini adalah seluruh WPOP Usahawan yang ada di wilayah KPP Kebayoran Baru Tiga Jakarta Selatan. Responden yang akan digunakan sebagai sampel dalam penelitian ini adalah WPOP usahawan dengan kriteria telah terdaftar sebagai wajib pajak dan minimal selama 1 tahun dan pernah menyampaikan SPT sebanyak 85 wajib pajak.

Penelitian ini melibatkan empat variabel yang terdiri atas satu variabel terikat (dependen) dan tiga variabel bebas (independen). Variabel terikatnya adalah kepatuhan pajak, sedangkan variabel bebas tersebut adalah: (1) perilaku individu, (2) motivasi, (3) pengetahuan pajak Pengumpulan data dalam penelitian ini dengan menggunakan metode survey ( kuesioner) kepada wajib pajak yang sedang menyerahkan SPT masa dan metode kepustakaan (Library Research).

\section{Metode Analisis}

Penyelesaian penelitian ini dengan menggunakan teknik analisis kuantitatif. Variabel perilaku individu, motivasi, pengetahuan pajak dan kepatuhan WPOP dalam penelitian ini diukur dengan menggunakan skala likert 5 tingkat yaitu angka 5 untuk pendapat sangat setuju (SS) dan angka 1 untuk sangat tidak setuju (STS). Pengujian hipotesis dilakukan menggunakan regresi linear berganda sebagai berikut:

$$
Y=\alpha+\beta_{1} X_{1}+\beta_{2} X_{2}+\beta_{3} X_{3}+e
$$

\section{Keterangan:}

$\mathrm{Y}=$ Kepatuhan Wajib Pajak WPOP, $\alpha=$ Bilangan konstanta $1 \beta \ldots n \beta=$ Koefisien arah regresi, $\mathrm{X}_{1}=$ Perilaku Individu, $\mathrm{X}_{2}=$ Motivasi, $\mathrm{X}_{3}=$ Pengetahuan pajak, $\mathrm{e}=$ kesalahan pengganggu (disturbance's error)

\section{HASIL DAN PEMBAHASAN Deskripsi Objek Penelitian}

Sampel tersebut diklasifikasi berdasarkan usia dan jenis kelamin, sebagaimana dapat dilihat pada tabel sebagai berikut:

Tabel 1

Tabulasi Silang Usia dan Jenis Kelamin

\begin{tabular}{|c|c|c|c|}
\hline USIA & \multicolumn{2}{|c|}{ JENIS KELAMIN } & TOTAL \\
\hline & $\mathrm{L}$ & $\mathrm{P}$ & \\
\hline $\mathbf{2 1 - 2 5}$ TAHUN & 1 & 4 & $5 \%$ \\
\hline & $1 \%$ & $4 \%$ & \\
\hline
\end{tabular}




\begin{tabular}{|c|c|c|c|}
\hline 26-30 TAHUN & 9 & 6 & $15 \%$ \\
\hline & $9 \%$ & $6 \%$ & \\
\hline 31-35 TAHUN & 26 & 8 & $34 \%$ \\
\hline 36- 40 TAHUN & $26 \%$ & $8 \%$ & \\
\hline & $20 \%$ & $6 \%$ & $26 \%$ \\
\hline $41-45$ TAHUN & 3 & 2 & $5 \%$ \\
\hline & $3 \%$ & $2 \%$ & \\
\hline TOTAL & 65 & 20 & $85 \%$ \\
\hline
\end{tabular}

Sumber :data primer hasil survei( 2017)

Berdasarkan pengelompokkan jenis kelamin dan usia diketahui bahwa responden laki-laki paling banyak 26\% dan perempuan $8 \%$ antara usia 31-35.

Tabel 2

Tabulasi Silang Pendidikan dan Jenis Kelamin

\begin{tabular}{|c|c|c|c|}
\hline & \multicolumn{2}{|c|}{ UENIS KELAMIN } & TOTAL \\
\hline & $\mathrm{L}$ & $\mathrm{P}$ & \\
\hline D. 3 & 13 & 16 & $29 \%$ \\
\hline & $13 \%$ & $16 \%$ & \\
\hline S.1 & 18 & 35 & $53 \%$ \\
\hline & $18 \%$ & $35 \%$ & \\
\hline S.2 & 2 & 1 & $3 \%$ \\
\hline & $2 \%$ & $1 \%$ & \\
\hline TOTAL & 53 & 32 & $85 \%$ \\
\hline
\end{tabular}

Sumber : data primer ( 2017)

Berdasarkan Tabel 2 dapat diketahui bahwa responden laki-laki maupun responden perempuan paling banyak memiliki tingkat pendidikan S1, yaitu laki-laki 35\% dan perempuan $18 \%$.

\section{Pengujian Hipotesis}

\section{Uji Koefisien Determinasi $\left(\mathbf{R}^{2}\right)$ dan Korelasi}

Koefisien determinasi (R2) pada intinya mengukur seberapa jauh kemampuan model dalam menerangkan variasi variabel dependen. Sedangkan Uji Korelasi 
digunakan untuk mengetahui hubungan dari variabel bebas terhadap variabel terikat.

\section{Tabel 3}

Koefisien Determinasi $\left(\mathrm{R}^{2}\right)$

Model Summary ${ }^{b}$

\begin{tabular}{|l|r|r|r|r|r|}
\hline Model & R & R Square & \multicolumn{1}{c|}{$\begin{array}{c}\text { Adjusted R } \\
\text { Square }\end{array}$} & $\begin{array}{c}\text { Std. Error of the } \\
\text { Estimate }\end{array}$ & Durbin-Watson \\
\hline 1 & $.872^{\mathrm{a}}$ & .760 & .751 & 1.72775 & 1.916 \\
\hline
\end{tabular}

a. Predictors: (Constant), Pengetahuan Pajak, Perilaku Individu, Motivasi

b. Dependent Variable: Kepatuhan Pajak WPOP

Sumber : Data diolah (2017)

Berdasarkan Tabel 3 dapat diketahui bahwa Adjusted $R$ Square = 0,751 yang berarti variabel perilaku individu, motivasi dan pengetahuan pajak memberikan pengaruh terhadap Kepatuhan Pajak Wajib Pajak Orang Pribadi

sebesar 75,1\%. Dengan demikian ada 24,9\% ( $100 \%-75,1 \%$ ) variabel lain yang memberikan pengaruh terhadap Kepatuhan Pajak Wajib Pajak Orang Pribadi selain variabel perilaku individu, motivasi dan pengetahuan pajak.

Pada tabel 3 diatas diperoleh angka korelasi antara perilaku individu, motivasi dan pengetahuan pajak terhadap kepatuhan pajak WPOP sebesar 0.872 , artinya antara variabel perilaku individu, motivasi dan pengetahuan pajak mempunyai hubungan yang sangat kuat dan searah. Searah artinya jika perilaku individu, motivasi dan pengetahuan pajak tinggi maka kepatuhan pajak WPOP meningkat

\section{Uji Signifikansi Parameter Individual (Uji Statistik t)}

Dilakukan untuk menguji apakah masing-masing variabel independen mempunyai pengaruh yang signifikan terhadap variabel dependennya.Uji t dalam penelitian ini meliputi perilaku individu, motivasi dan pengetahuan pajak sebagai variabel independen dan kepatuhan pajak WPOP sebagai variabel dependennya. Untuk melihat besarnya pengaruh digunakan angka beta atau Standartize Coefficient yang ditunjukkan pada tabel 4.

Tabel 4

Coefficients $^{\mathrm{a}}$

\begin{tabular}{|c|c|c|c|c|c|c|c|}
\hline \multirow[b]{2}{*}{ Model } & \multicolumn{2}{|c|}{$\begin{array}{c}\text { Unstandardized } \\
\text { Coefficients }\end{array}$} & \multirow{2}{*}{\begin{tabular}{|c|c}
$\begin{array}{c}\text { Standardized } \\
\text { Coefficients }\end{array}$ \\
Beta
\end{tabular}} & \multirow[b]{2}{*}{$\mathrm{t}$} & \multirow[b]{2}{*}{ Sig. } & \multicolumn{2}{|c|}{ Collinearity Statistics } \\
\hline & B & Std. Error & & & & Tolerance & VIF \\
\hline
\end{tabular}




\begin{tabular}{|l|r|r|r|r|r|r|r|}
\hline 1 (Constant) & -2.218 & 1.659 & & -1.337 & .184 & & \\
\cline { 2 - 7 } Perilaku Individu & .054 & .019 & .118 & 2.911 & .004 & .960 & 1.042 \\
\hline Motivasi & .488 & .050 & .549 & 9.670 & .000 & .489 & 2.045 \\
\multicolumn{1}{l|}{ Pengetahuan Pajak } & .371 & .050 & .419 & 7.481 & .000 & .503 & 1.989 \\
\hline
\end{tabular}

a. Dependent Variable: Kepatuhan Pajak WPOP

Sumber : Data diolah (2017)

Berdasarkan tabel 4 pada kolom Unstandartized Coefficient digunakan untuk membuat persamaan regresi. Karena nilai konstanta (constant) $=-2,218$ dan nilai untuk perilaku individu $=0,054$, motivasi $=0,488$ dan pengetahuan pajak $=0,371$, maka persamaan regrasi untuk variabel perilaku individu $\left(\mathrm{X}_{1}\right)$, motivasi $\left(\mathrm{X}_{2}\right)$, pengetahuan pajak $\left(\mathrm{X}_{3}\right)$ serta kepatuhan pajak WPOP ( $\left.\mathrm{Y}\right)$ tersebut dapat ditulis persamaan regresi sebagai berikut :

$$
Y=-2,218+0,054 X_{1}+0,488 X_{2}+0,371 X_{3}+e
$$

Nilai thitung untuk variabel perilaku individu adalah sebesar 2,911 dengan taraf signifikan sebesar $0,004<0,05$. Hal ini menunjukkan bahwa thitung lebih besar dari tabel $(2,911>1,663)$, artinya terdapat pengaruh yang signifikan dari variabel perilaku individu terhadap kepatuhan pajak WPOP usahawan, atau dapat dikatakan bahwa hasil penelitian ini menolak $\mathrm{H}_{\mathrm{o}}$ (perilaku individu berpengaruh negatif terhadap kepatuhan pajak) dan menerima $\mathrm{H}_{\mathrm{a}}$ ( perilaku individu berpengaruh positif terhadap kepatuhan pajak).

Nilai thitung untuk variabel motivasi sebesar 9,670 dengan taraf signifikan sebesar $0,000<0,05$. Hal

ini menunjukkan bahwa thitung lebih besar dari tabel

$(9,670>1,663)$, artinya terdapat pengaruh yang signifikan dari variabel motivasi terhadap kepatuhan pajak WPOP usahawan atau dapat dikatakan bahwa hasil penelitian ini menolak $\mathrm{H}_{\mathrm{o}}$ ( motivasi berpengaruh negatif terhadap kepatuhan pajak) dan menerima $\mathrm{H}_{\mathrm{a}}$ ( motivasi berpengaruh positif terhadap kepatuhan pajak).

Nilai thitung untuk variabel pengetahuan pajak sebesar 7,481 dengan taraf signifikan sebesar $0,000<0,05$. Hal ini menunjukkan bahwa thitung lebih besar dari tabel $(7,481>1,663)$, artinya terdapat pengaruh yang signifikan dari variabel pengetahuan pajak berpengaruh terhadap kepatuhan pajak WPOP usahawan atau dapat dikatakan bahwa hasil penelitian ini menolak $\mathrm{H}_{\mathrm{o}}$ (pengetahuan pajak berpengaruh negatif terhadap kepatuhan pajak ) dan menerima $\mathrm{H}_{\mathrm{a}}$ ( pengetahuan pajak berpengaruh positif terhadap kepatuhan pajak ). 


\section{Gambar 3}

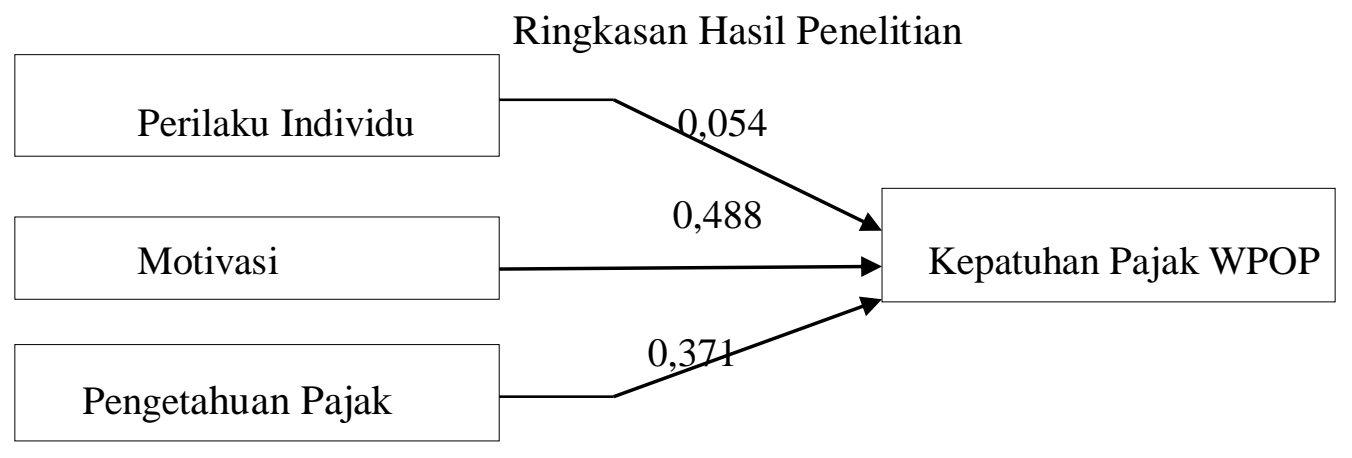

Pada gambar 3 diatas dapat dilihat ringkasan hasil penelitian. Hasil penelitian ini menunjukkan bahwa pada hasil uji t diperoleh untuk variabel perilaku sebesar 0,054 , motivasi $=0,488$ dan pengetahuan pajak $=0,371$ berpengaruh signifikan terhadap kepatuhan pajak orang pribadi. Hal ini sesuai dengan teori perilaku terencana ( The theory of planned behavior) dan teori yang dikemukakan oleh James L. Gibson mengenai perilaku wajib pajak dalam memenuhi kewajiban perpajakannya sehingga akan terlihat seberapa besar kepatuhan wajib pajak yang meliputi penghitungan, pembayaran dan pelaporan pajaknya. Dengan demikian dapat dikatakan bahwa ketiga faktor tersebut sangatlah berkaitan satu sama lainnya dalam mempengaruhi kepatuhan perpajakan bagi wajiab pajak dalam memenuhi kewajibannya. Hal ini juga terlihat pada uji determinasi yang menjelaskan bahwa variabel perilaku individu, motivasi dan pengetahuan pajak memberikan pengaruh terhadap Kepatuhan Pajak Wajib Pajak Orang Pribadi sebesar 75,1\%. Dengan demikian ada 24,9\% ( $100 \%$ - 75,1 \%) variabel lain yang memberikan pengaruh terhadap Kepatuhan Pajak Wajib Pajak Orang Pribadi.

\section{SIMPULAN}

Berdasarkan data dan pengolahan di atas dapat disimpulkan bahwa faktor perilaku individu,motivasi dan pengetahuan pajak memberikan kontribusi pada kepatuhan wajib pajak dalam membayar pajak sebasar 75,1\% sementara $24,9 \%$ dijelaskan oleh variabel lain yang tidak dipergunakan dalam penelitian ini.Hal ini berarti bahwa apabila ada peningkatan atau penurunan dari nilai variabel tersebut dapat berpengaruh terhadap kepatuhan pajakWPOP. 


\section{DAFTAR PUSTAKA}

\section{PENELITIAN}

Anangga, Septian 2012. Studi Empiris Pada Penggunaan aplikaasi Pajak:Integrasi Theory Of Planned Behavior dan Technology acceptance Model. Skripsi. Universitas Diponegoro

Blanthorne, C. M. 2011. The Role of Opportunity and Beliefs On Tax Evasion: A Structural Equation Analysis. Dissertation. Arizona State University.

Bobek, D., Richard C. Hatfield, 2007. An Investigation of Theory of Planned Behavior ahn the Role of Moral Obligation in Tax Compliance. Behavioral Research in Accounting, 15

Harinurdin,Erwin,2009,Perilaku Kepatuhan Wajib Pajak Badan, Bisnis \& Birokrasi, Jurnal Ilmu Administrasi dan Organisasi, Volume 16, Nomor 2

Mustikasari, Elia, 2007. Kajian Empiris tentang Kepatuhan Wajib Pajak Badan di Perusahaan Industri Pengolahan di Surabaya. Simposium Nasional Akuntansi X:142

Nurmantu, Safri. 2007. Faktor- Faktor yang mempengaruhi Pelayanan Perpajakan. Jurnal Ilmu Adminstrasi dan Organisasi,Bisnis \& Birokrasi, Vol.15, No.1 (Januari).

Palil,M,Rizal. 2005. Does Tax Knowledge Mater in Self Assessment System Evidence from Malaysia Tax Administrative. The Journal of American Academy of Business. Cambrige, No.2.Maret

Prabu, Anwar 2005, 'Pengaruh Motivasi Terhadap Kepuasan Kerja Pegawai Badan Koordinasi Keluarga Berencana Nasional Kabupaten Muara Enim', Jurnal Manajemen \& Bisnis Sriwijaya, vol. 3, no. 6, hal. 1-25 dari (http://digilib.unsri.ac.id/download/Jurnal\%20MM\%20Vol\%203\%20No\%206\%20 Artike1\%204\%20Anwar\%20Prabu.pdf, diakses 29 Juli 2012).

Widayati. 2010.Faktor -Faktor yang Mempengaruhi Kemauan Untuk Membayar Pajak Wajib Pajak Orang Pribadi Yang Melakukan Pekerjaan Bebas (Studi Kasus pada KPP Pratama Gambir Tiga) : Simposium Nasional Akuntansi XIII Purwokerto 2010

\section{BUKU REFERENSI}


Ajzen, Icek, 2002. Constructing TPB Questionnaire: Conceptual and Methodological Consideration. September (Refised January, 2006)

Brotodihardjo R. Sumitro,1990, Pengantar Ilmu Hukum Pajak, Bandung : PT. Eresco.

Widayatun, Tri Rusmi, 1999, Ilmu Perilaku, cetakan pertama, Jakarta, CV. Sagung Seto

PERATURAN

Peraturan Menteri Keuangan.No.192 /PMK.03/ 2007 tentang kriteria Wajib Pajak Patuh Jo. No.74/ PMK.03/2012

\section{WEBSITE}

Sri Mulyani: “Tax Ratio Indonesia Terendah, "www.warta

ekonomi.co.id.Indonesia.tanggal 10 januari 2017.

www. Kumparan.com:” Hingga 31 Maret 2017, Realisasi Penerimaan Pajak Capai

Rp 222 Triliun.” Tanggal 3 april 2017 